\title{
Hubungan Kebiasaan Sarapan dengan Status Gizi Siswa di SD Negeri Kedung Waringin 01
}

(Relationship Between Breakfast Habit and Nutritional Status Student's in SD Negeri Kedung Waringin 01)

\author{
Winnie Tunggal Mutika' ${ }^{1 *}$, Magda Doria $^{1}$, Ambariani $^{1}$ \\ 1Program Studi Kebidanan Universitas Gunadarma \\ *Koresponden Penulis : winniemutika@gmail.com
}

\begin{abstract}
ABSTRAK
Penelitian ini dilakukan untuk mengetahui hubungan antara kebiasaan sarapan dengan status gizi siswa SDN Kedung Waringin 01. Desain penelitian analitik menggunakan pendekatan cross sectional study. Pengambilan sampel menggunakan teknik purposive sampling dengan sampel siswa kelas V sebanyak 49 orang. Pengukuran status gizi menggunakan Indeks Massa Tubuh. Pengelompokan kebiasaan sarapan selama seminggu terakhir yaitu tidak pernah, jarang dan selalu sarapan. Pengambilan data dimulai dari tanggal 3-10 Maret 2017. Hasil uji Fisher Exact dengan tingkat signifikansi $5 \%$ atau 0,05 didapatkan nilai $\mathrm{p}<0,05(\mathrm{p}=0,004)$. Hasil penelitian menunjukkan 59,1\% atau 29 siswa memiliki Indeks massa tubuh normal, 2,1\% atau 1 siswa memiliki indeks massa tubuh sangat kurus, 6,1\% atau 3 siswa memiliki indeks massa tubuh kurus, $24,2 \%$ atau 12 siswa memiliki indeks massa tubuh gemuk dan $8,2 \%$ atau 4 siswa memiliki indeks massa tubuh obesitas. Kesimpulan penelitian bahwa terdapat hubungan antara kebiasaan sarapan dengan status gizi siswa. Siswa yang jarang dan tidak pernah mengkonsumsi sarapan pagi memicu timbulnya status gizi yang tidak baik.
\end{abstract}

Kata kunci: Kebiasaan sarapan, indeks massa tubuh, status gizi.

\section{ABSTRACT}

This research intended to discover relationship between breakfast habit and nutrition status students's in SDN Kedung Waringin 01. Method: Research design used was cross sectional study approach. Sample taking conducted using purposive sampling with sample of 49 grade V students. Breakfast habit grouping over the past one week comprised of never, rarely and always have breakfast. Data collection initiated from March 3rd through March 10th, 2017. Fisher Exact test result with $5 \%$ or 0.05 significance level yielding $p<0.05$ value ( $p=0.004)$. Results: First, $59,1 \%$ or 29 students have normal body mass index, $2,1 \%$ or one student has very thin body mass index, 6,1 $\%$ or 3 students have thin body mass index, 24,2 or 12 students have fat body mass index and 8,2 or 4 students have obesity body mass index. Second, $47 \%$ or 23 students always have breakfast, 22,4\% or 11 students never have brekafast and 30,6\% or 15 students rarely have breakfast. Fisher Exact test result with $5 \%$ or 0.05 significance level yielding $p<0.05$ value $(p=0.004)$. Conclusion: According to research result it could be concluded that there was relationship between breakfast habit with student nutrition status. Student who rarely and never had breakfast triggered poor nutrition status.

Keywords: Breakfast habit, body mass index, nutritional status 
2 | Jurnal Kesmas Untika Luwuk: Public Health Journal, 11 (1) : 1-6

\section{PENDAHULUAN}

Pengertian gizi menurut KBBI (Kamus Besar Bahasa Indonesia)(KBBI, 2016) adalah zat makanan pokok yang diperlukan bagi pertumbuhan dan kesehatan badan. Menurut National Library of Medicine, status gizi adalah keseimbangan antara asupan zat gizi dan jumlah yang dibutuhkan tubuh untuk melakukan kegiatan. Anak usia sekolah (usia 5-12 tahun) memerlukan asupan gizi yang baik untuk menopang pertumbuhan dan perkembangan. Salah satu cara untuk memenuhi asupan gizi harian anak usia sekolah adalah sarapan. Sarapan pagi menurut situs Merriam-Webster (Merriam Webster, 2016) adalah makanan pertama di pagi hari, sedangkan menurut Cambridge Dictionary (Cambridge Dictionary, 2016). Sarapan adalah makanan di pagi hari sebagai makanan pertama di hari itu. Sarapan disinyalir mempengaruhi asupan energi yang juga berpengaruh terhadap status gizi. Pengukuran status gizi untuk anak usia sekolah berdasarkan Kemenkes tahun 2011 (Kemenkes, 2011) menggunakan Indeks Massa Tubuh (IMT). Siswa di SDN Kedung Waringin tidak terbiasa sarapan yang berkaitan dengan menurunnya prestasi belajar, gangguan konsentrasi belajar, serta meningkatkan risiko obesitas dan gangguan kesehatan lainnya. Sedangkan sarapan penting dilakukan untuk memenuhi 20-25\% kecukupan energi total dalam sehari.

Tujuan dari penelitian ini adalah mengetahui hubungan antara kebiasaan sarapan pagi dengan status gizi pada siswa sekolah dasar di SDN Kedung Waringin 01.

\section{METODE PENELITIAN}

Jenis penelitian ini survei analitik dengan menggunakan rancangan case control. Penelitian dilakukan pada tanggal 3 sampai 10 Maret 2017 di SDN Kedung Waringin 01 tahun ajaran 2016/2017, Desa Kedung Waringin Kecamatan Bojonggede Kabupaten Bogor. Rancangan studi pada penelitian ini adalah studi analitik dan pendekatan potong lintang mengenai hubungan sarapan pagi dengan status gizi di SDN Kedung Waringin 01. Data yang diperoleh adalah data primer siswa kelas lima SDN Kedung Waringin 01. Variabel independen pada penelitian ini adalah kebiasaan sarapan dan varibel dependen pada penelitian ini adalah status gizi anak usia sekolah. Kerangka konsep pada penelitian ini adalah kebiasaan sarapan mempengaruhi status gizi. Populasi pada penelitian ini adalah seluruh siswa SDN Kedung Waringin 01 dan sampel adalah siswa kelas lima di SDN Kedung Waringin 01 tahun ajaran 2016/2017 yang hadir pada saat penelitian dilakukan. Pengambilan sampel menggunakan teknik purposive sampling dengan sampel siswa kelas V sebanyak 49 orang.

Pengumpulan data dalam penelitian ini dilakukan dengan metode kuesioner, pengukuran tinggi badan dengan microtoise, dan pengukuran berat badan dengan timbangan injak. Analisis data dilakukan dengan menggunakan program Microsoft Excell 2010 dan SPSS (Statistical Program for Social Science) 16.0 for Windows. Analisis data menggunakan uji $\chi 2$ (chi square). Apabila ada satu sel atau lebih yang nilainya kurang dari 5, analisis data menggunakan uji Eksak Fisher.

\section{HASIL}

Berdasarkan penelitian yang dilakukan pada tanggal 3-10 Maret tahun 2017 didapatkan beberapa karakteristik responden yakni usia, jenis kelamin dan IMT. Dalam karakteristik usia, siswa berusia 10 tahun berjumlah 13 orang dengan kebiasaan tidak pernah sarapan sejumlah 6 orang, jarang sarapan 3 orang dan selalu sarapan 4 orang. Siswa usia 11 tahun sejumlah 26 orang, dengan kebiasaan tidak pernah sarapan 
sejumlah 2 orang, jarang sarapan 8 orang dan selalu sarapan 16 orang. Siswa usia 12 tahun sejumlah 10 orang, dengan kebiasaan tidak pernah sarapan sejumlah 4 orang, jarang sarapan 3 orang dan selalu sarapan 3 orang.

Karakteristik jenis kelamin didapatkan siswa dengan jenis kelamin laki-laki sebanyak 22 orang dan perempuan sebanyak 27 orang. Siswa laki-lakiyang tidak pernah sarapan sebanyak 5 orang, jarang sarapan 6 orang, dan selalu sarapan 11 orang. Siswa perempuan yang tidak pernah sarapan sejumlah 6 orang, jarang sarapan 9 orang dan selalu sarapan sejumlah 12 orang.

Karakteristik untuk IMT terbagi menjadi 4 yaitu sangat kurus, kurus, normal, gemuk dan obesitas. Siswa dengan IMT sangat kurus yang tidak pernah sarapan sebanyak 1 orang, jarang sarapan dan selalu sarapan sebanyak 0 orang. Siswa dengan IMT kurus yang terbiasa tidak sarapan sejumlah 0 orang, jarang sarapan sejumlah 1 orang dan selalu sarapan sejumlah 2 orang. Siswa dengan IMT normal yang terbiasa tidak sarapan sejumlah 2 orang, jarang sarapan sejumlah 11 orang dan selalu sarapan sejumlah 16 orang. Siswa dengan IMT gemuk yang terbiasa tidak sarapan sejumlah 6 orang, jarang sarapan sejumlah 3 orang dan selalu sarapan sejumlah 3 orang. Siswa dengan IMT obesitas yang terbiasa tidak sarapan sejumlah 1 orang, jarang sarapan sejumlah 1 orang dan selalu sarapan sejumlah 2 orang. Hal tersebut dapat di uraikan sebagai berikut:

Tabel 1. Karakteristik Responden Penelitian Hubungan Sarapan dengan Status Gizi

\begin{tabular}{|c|c|c|c|c|}
\hline \multirow{2}{*}{ Karakteristik } & \multicolumn{3}{|c|}{ Kebiasaan Sarapan } & \multirow{2}{*}{ Jumlah } \\
\hline & Tidak Pernah & Jarang & Selalu & \\
\hline \multicolumn{5}{|c|}{ Huan terian } \\
\hline 10 & 6 & 3 & 4 & 13 \\
\hline 11 & 2 & 8 & 16 & 26 \\
\hline 12 & 4 & 3 & 3 & 10 \\
\hline \multicolumn{5}{|l|}{ Jenis Kelamin } \\
\hline Laki-laki & 5 & 6 & 11 & 22 \\
\hline Perempuan & 6 & 9 & 12 & 27 \\
\hline \multicolumn{5}{|l|}{ IMT } \\
\hline Sangat Kurus & 1 & 0 & 0 & 1 \\
\hline Kurus & 0 & 1 & 2 & 3 \\
\hline Normal & 2 & 11 & 16 & 29 \\
\hline Gemuk & 6 & 3 & 3 & 12 \\
\hline Obesitas & 2 & 0 & 2 & 4 \\
\hline
\end{tabular}

Pada hasil penelitian didapatkan dari 11 siswa yang tidak pernah sarapan pagi didapatkan 1 orang (9\%) dengan status gizi sangat kurus, 0 orang $(0 \%)$ dengan status gizi kurus, 2 orang $(18,1 \%)$ dengan status gizi normal, 6 orang $(54,5 \%)$ dengan status gizi gemuk dan 2 orang $(18,1 \%)$ dengan status gizi obesitas. Siswa yang jarang sarapan pagi berjumlah 15 orang terdiri dari 0 siswa $(0 \%)$ dengan status gizi sangat kurus, 1 orang $(6,7 \%)$ dengan status gizi kurus, 11 orang $(73,3 \%)$ dengan status gizi normal, 3 orang $(20 \%)$ dengan status gizi gemuk dan 0 orang $(0 \%)$ dengan status gizi obesitas. Siswa yang selalu sarapan pagi berjumlah 23 orang terdiri dari 0 siswa $(0 \%)$ dengan status gizi sangat kurus, 2 orang $(8,6 \%)$ dengan status gizi kurus, 16 orang $(69,5 \%)$ dengan status gizi normal, 3 orang (13\%) dengan status gizi gemuk dan 2 orang $(8,6 \%)$ dengan status gizi obesitas. Hal tersebut dapat di uraikan sebagai berikut: 
4 | Jurnal Kesmas Untika Luwuk: Public Health Journal, 11 (1) : 1-6

Tabel 2. Hubungan Kebiasaan Sarapan dengan Status Gizi

\begin{tabular}{lccccc}
\hline \multirow{2}{*}{ Sarapan } & \multicolumn{5}{c}{ Status Gizi } \\
\cline { 2 - 6 } & Sangat Kurus & Kurus & Normal & Gemuk & Obesitas \\
\hline Tidak Pernah & $1(9)$ & $0(0)$ & $2(18,1)$ & $6(54,5)$ & $2(18,1)$ \\
Jarang & $0(0)$ & $1(6,7)$ & $11(73,3)$ & $3(20)$ & $0(0)$ \\
Selalu & $0(0)$ & $2(8,6)$ & $16(69,5)$ & $3(13)$ & $2(8,6)$ \\
Jumlah & $1(2)$ & $3(6,1)$ & $29(59,2)$ & $12(24,5)$ & $4(8,2)$ \\
\hline
\end{tabular}

Pada tabel di atas, beberapa kategori jumlahnya terlalu kecil. Untuk memudahkan penghitungan, tabel diubah kedalam bentuk 2x2 dengan menggabungkan beberapa kategori. Dalam variabel sarapan kategori yang digabungkan adalah kategori jarang sarapan dan selalu sarapan menjadi kategori sarapan. Sedangkan dalam variabel status gizi kategori yang digabungkan adalah kategori sangat kurus, kurus, gemuk dan obesitas menjadi kategori tidak normal. Sehingga didapatkan tabel sebagai berikut:

Tabel 3. Hubungan Kebiasaan Sarapan dengan Status Gizi (Tabel 2X2)

\begin{tabular}{|c|c|c|c|c|}
\hline \multirow[b]{2}{*}{ Sarapan } & \multicolumn{2}{|c|}{ Status Gizi } & \multirow[b]{2}{*}{ OR } & \multirow{2}{*}{ Nilai $p$} \\
\hline & Tidak Normal & Normal & & \\
\hline Tidak Pernah & $9(81,8)$ & $2(18,2)$ & 11,04 & 0,004 \\
\hline Sarapan & $11(28,9)$ & $27(71,1)$ & & \\
\hline Jumlah & $20(40,8)$ & $29(59,2)$ & & \\
\hline
\end{tabular}

Hasil uji statistik didapatkan $p=0,004$, dapat disimpulkan ada hubungan antara kebiasaan sarapan pagi dengan status gizi pada siswa SDN Kedung Waringin 01 tahun ajaran 2016/2017.

\section{PEMBAHASAN}

Pada penelitian ini, terdapat beberapa keterbatasan antara lain peneliti hanya melakukan pengukuran terhadap indeks massa tubuh untuk mengetahui status gizi siswa sekolah dasar. Keterbatasan penelitian lainnya adalah peneliti tidak melakukan peninjauan mengenai menu sarapan pagi anak, penyakit, kebiasaan jajan, pendidikan dan pendapatan orang tua yang mungkin dapat mempengaruhi indeks massa tubuh. Seharusnya, peneliti melakukan pemeriksaan lebih lanjut mengenai hal tersebut. Namun, karena keterbatasan waktu dan pemeriksaan peneliti tidak melakukan penelitian lebih lanjut.

Tabel 1 menunjukkan bahwa responden terbanyak berdasarkan karakteristik usia ada pada usia 11 tahun dengan jumlah responden 26 orang. Ditinjau dari kebiasaan sarapan, kebiasaan tidak pernah sarapan paling banyak didapatkan pada karakteristik usia 12 tahun, yaitu sebanyak 7 orang. Kebiasaan jarang sarapan dan selalu sarapan terbanyak didapatkan pada karakteristik usia 11 tahun sebanyak 8 orang dan 17 orang. Pada penelitian ini, terlihat bahwa siswa usia 11 tahun lebih teratur untuk sarapan pagi dibandingkan dengan siswa usia 12 tahun dan siswa usia 10 tahun. Hal ini dipengaruhi oleh distribusi siswa kelas lima di SDN Kedung Waringin 01 yang lebih banyak didominasi oleh siswa usia 11 tahun.

Siswa dengan usia yang memiliki usia lebih tua memiliki frekuensi paling sedikit dalam kebiasaan sarapan dan frekuensi terbanyak dalam kebiasaan tidak pernah sarapan. Usia menentukan kedewasaan seseorang. Usia siswa yang lebih tua dipandang lebih dewasa oleh orang tua sehingga membuat kebiasaan sarapan siswa pada usia tersebut kurang dipantau oleh para orang tua. 
Dalam karakteristik jenis kelamin, responden terbanyak didapatkan pada karakteristik jenis kelamin perempuan dengan jumlah responden 27 orang. Pada kedua karakteristik tersebut, kategori selalu sarapan menjadi kategori yang banyak ditemukan dengan jumlah 11 orang pada siswa laki-laki dan 12 orang pada siswa perempuan.

Pada tabel 1 ditemukan bahwa frekuensi siswa dengan status gizi sangat kurus sebanyak 1 orang $(2,1 \%)$ dan kurus sebanyak 3 orang $(6,1 \%)$ dari 49 siswa. Menurut Riskesdas tahun 2013 prevalensi kurus anak usia 5-12 tahun menurut IMT per umur secara nasional adalah 7,2\% dan prevalensi sangat kurus adalah 4,0\%. Hal ini menunjukkan bahwa prevalensi anak dengan IMT sangat kurus dan kurus di SDN Kedung Waringin 01 tahun 2016/2017 sudah baik karena di bawah prevalensi nasional.

Frekuensi siswa dengan status gizi gemuk adalah 12 siswa $(24,4 \%)$. Sedangkan, menurut Riskesdas tahun 2013 prevalensi nasional gemuk pada anak usia 5-12 tahun adalah 10,8\%. Angka tersebut masih sangat tinggi jika dibandingkan dengan prevalensi nasional.

Prevalensi untuk sangat gemuk atau obesitas pada anak usia 5-12 tahun berdasarkan IMT per umur adalah 8,8\%. Pada penelitian yang dilakukan di SDN Kedung Waringin 01 didapatkan anak dengan obesitas sebanyak 4 orang atau 8,2\%. Hal ini berarti angka anak obesitas di SDN Kedung Waringin 01 baik karena berada di bawah prevalensi nasional.

Pada penelitian ini ditemukan bahwa frekuensi siswa dengan status gizi sangat kurus dan kurus lebih kecil dibandingkan dengan frekuensi siswa dengan status gizi gemuk dan obesitas. Hal ini dapat disebabkan oleh beberapa faktor diantaranya kebiasaan jajan siswa. Akses yang mudah untuk mendapatkan jajanan serta bentuk, warna dan rasa yang beragam menyebabkan anak-anak lebih tertarik untuk memakan jajanan tanpa memedulikan nilai gizi yang terdapat dalam jajanan tersebut. Bahkan, hal ini juga membuat anak yang sudah sarapan menjadi tertarik untuk membeli jajanan. Jajanan biasanya memiliki kandungan lemak dan gula yang lebih banyak dibandingkan dengan makanan di rumah. Selain itu, kurangnya pengawasan dan pengetahuan orangtua juga dapat mempengaruhi kebiasaan anak dalam memilih jajanan yang dikonsumsi.

Berdasarkan hasil penelitian, ditemukan hubungan antara kebiasaan sarapan pagi dengan status gizi pada siswa SDN Kedung Waringin 01 tahun ajaran 2016/2017 $(p=0,004)$. Hal ini sesuai dengan penelitian yang dilakukan oleh Yulyastri (Yulyastri, 2014) di Bantul tahun 2014 ( $p=0,001$ ). Pada penelitian ini, dari 47 siswa, terdapat 34 responden yang memiliki status gizi kurus, 12 responden dengan status gizi normal, dan 1 responden dengan status gizi gemuk.

Terdapat perbedaan yang mencolok antara penelitian yang dilakukan oleh Yulyastri dengan hasil penelitian yang dilakukan di SD Kedung Waringin 01. Penelitian Yulyastri menunjukkan lebih banyak siswa yang memiliki status gizi kurus, sedangkan hasil penelitian di SD Kedung Waringin 01 menunjukkan lebih banyak siswa memiliki status gizi gemuk dan obesitas. Hal ini dapat dipengaruhi oleh perbedaan aktivitas siswa sekolah dasar di masing-masing wilayah, kebiasaan jajan, serta akses untuk mendapatkan makanan.

Penelitian lainnya yang menunjukkan adanya hubungan antara kebiasaan sarapan dan status gizi adalah penelitian oleh Ahmad, et al (S. Ahmada \& F Waluyo, 2011) tahun 2011 di Yogyakarta $(p=0,002)$. Penelitian ini menunjukkan sebanyak 20 
6 | Jurnal Kesmas Untika Luwuk: Public Health Journal, 11 (1) : 1-6

siswa yang tidak terbiasa sarapan 15 diantaranya memiliki status gizi tidak normal, dan 5 diantaranya memiliki status gizi normal. Dari status gizi yang tidak normal tersebut, gemuk dan obesitas memiliki jumlah yang paling banyak. Hal ini sesuai dengan penelitian yang dilakukan di SD Kedung Waringin 01.

Menurut Rampersaud (Rampersaud, 2009), sarapan mencukupi kebutuhan nutrisi harian anak. Nutrisi harian yang dibutuhkan oleh anak seperti protein sangat penting untuk masa pertumbuhan. Konsumsi protein yang cukup mempengaruhi status gizi anak. Protein mengandung enzim yang berhubungan dengan metabolisme tubuh (Marista, 2010)(Mariza \& Kusumastuti, 2013).

Sarapan juga membuat seseorang cenderung untuk lebih memilih makanan yang sehat. Dalam hal ini, sarapan membuat anak mengurangi jajan, sehingga mengurangi risiko anak mengalami obesitas.

\section{KESIMPULAN DAN SARAN}

Kesimpulan penelitian bahwa terdapat hubungan antara kebiasaan sarapan dengan status gizi siswa. Siswa yang jarang dan tidak pernah mengonsumsi sarapan pagi memicu timbulnya status gizi yang tidak baik. Tenaga kesehatan maupun tenaga pengajar di sekolah hendaknya mengedukasi dan menekankan pentingnya sarapan pagi kepada siswa dan orangtua siswa.

\section{DAFTAR PUSTAKA}

Cambridge Dictionary, C. (2016). Cambridge Dictionary.

KBBI. (2016). Kementerian Pendidikan dan Kebudayaan.

Kemenkes. (2011). Pengukuran status gizi untuk anak usia sekolah berdasarkan.

Mariza, Y. Y., \& Kusumastuti, A. C. (2013). HUBUNGAN ANTARA KEBIASAAN SARAPAN DAN KEBIASAAN JAJAN DENGAN STATUS GIZI ANAK SEKOLAH DASAR DI KECAMATAN PEDURUNGAN KOTA SEMARANG. Journal of Nutrition College. https://doi.org/10.14710/jnc.v2i1.2108

Merriam Webster. (2016). Definition of Heat Of Solution by Merriam-Webster. Encyclopedia Britannica.

Rampersaud, G. C. (2009). Benefits of Breakfast for Children and Adolescents: Update and Recommendations for Practitioners. American Journal of Lifestyle Medicine. https://doi.org/10.1177/1559827608327219

S. Ahmada \& F Waluyo. (2011). Hubungan Kebiasaan Sarapan Pagi dan Jajan dengan Status Gizi Anak Sekolah Dasar di SD Negeri Kledokan Depok Sleman Yogyakarta. Universitas Respati Yogyakarta.

Yulyastri, R. and W. (2014). Hubungan Pola Makan Pagi dengan Status Gizi Siswa di SD Muhammadiyah Bendo Sradakan Bantul. STIKES 'Aisyiyah. 